doi:10.1017/aju.2018.36

\title{
SYMPOSIUM ON THOMAS FRANCK’S “EMERGING RIGHT TO DEMOCRATIC GOVERNANCE” AT 25
}

\section{TOWARD AN INSTRUMENTAL RIGHT TO DEMOCRACY}

\author{
Khalifa A. Alfadhel*
}

The downfall of the Soviet Bloc in the early 1990s led to an atmosphere of exaggerated victory, notably captured in Francis Fukuyama's famous book, The End of History, which celebrated the ideological triumph of democracy as a unanimously agreed-upon ideal form of government. ${ }^{1}$ The international law literature was not immune from the sense of democratic rejoicing. Of special note in this regard was the notion of an entitlement to democracy, introduced by the late Thomas Franck. ${ }^{2}$ Drawing on ideas of self-determination in international law, which themselves date back to the American Declaration of Independence, ${ }^{3}$ Franck postulated an "emerging right to democratic governance." He stipulated that "[s]elf-determination postulates the right of a people organised in an established territory to determine its collective political destiny in a democratic fashion and is therefore at the core of the democratic entitlement." 4 This essay considers Franck's claims, and argues that his view of democracy was too thin; instead, the essay argues for an instrumental conception of democracy that ties it to other rights and entitlements.

The connections between the right to self-determination and the right to political participation are complex, and proceeding axiomatically does not help resolve the real question in the minds of international lawyers and contemporary social contract theorists: is there really a right to democracy in international law? In what follows, I consider where the right to democracy stands, twenty-five years after Thomas Franck's classic article. I will argue that the right in question is, at best, procedural in nature, and that international law has not yet been able to address the substantive elements of a right to democratic governance. The right that has emerged is a relatively thin one that includes only the rights to vote and to be elected, but these alone are likely to be ineffective so long as they do not incorporate the deeper theoretical foundations of democratic governance. Instead of being satisfied with a thin descriptive view of what the right to democracy contains, I argue that we should adopt what I call an instrumental view, which recognizes democracy as an instrument to enforce other, mutually reinforcing rights and fundamental freedoms.

\footnotetext{
* Secretary General, National Institution for Human Rights (Babrain); Member of Board of Trustees, Bahrain Centre for Strategic, International and Energy Studies (Derasat).

1 See Francis Fukuyama, The End of History and the Last Man (1992).

2 Thomas M. Franck, The Emerging Right to Democratic Governance, 86 AJIL 46 (1992).

${ }^{3} I$ d. at $48-49$.

${ }^{4}$ Id. at 52.
}

The American Society of International Law and Khalifa A. Alfadhel @ 2018. This is an Open Access article, distributed under the terms of the Creative Commons Attribution licence (http://creativecommons.org/licenses/by/4.0/), which permits unrestricted re-use, distribution, and reproduction in any medium, provided the original work is properly cited. 


\section{Thin Democracy and the Problem of Political Intolerance}

It is important to start answering the question of whether there is a right to democracy by making the important distinction between the right to political participation and the right to self-determination, which together were the cornerstones of Franck's understanding of the democratic entitlement. The Human Rights Committee, in General Comment 25, clarified the distinct nature of these rights:

The rights under article 25 [the right to vote and to be elected] are related to, but distinct from, the right of peoples to self-determination. By virtue of the rights covered by article 1(1), peoples have the right to freely determine their political status and to enjoy the right to choose the form of their constitution or government. Article 25 deals with the right of individuals to participate in those processes which constitute the conduct of public affairs. Those rights, as individual rights, can give rise to claims under the first Optional Protocol. ${ }^{5}$

Hence, the right of peoples to self-determination is a collective right, while the right to political participation is an individual one. The collective right is, at this point, well enshrined in international law, subject to fairly consistent state practice. The individual right, on the other hand, is agreed upon at a normative level, but not implemented in countries which lack free and fair elections. Even in Franck's conception, the right to democratic governance is still "emerging," meaning that he understands that state practice is not consistent. In this sense, one might say that the right to democratic governance is more of a scholarly concept rather than a legal entitlement.

Another challenge to the idea of a "right" to democracy is the problem of political intolerance, which remains one of the most serious threats to democracy as a form of government. The recent experience of the Arab Spring is an important example, because procedural democracy was arguably one of the reasons for its failure. Many of the political movements that performed well in elections-including the Muslim Brotherhood, Salafists, and Shiite fundamentalists-were themselves not committed to democracy in any deep sense, but instead had their own conceptions of the good, inconsistent with liberal democracy (however defined) ${ }^{6}$

The key international law instruments, namely, the Universal Declaration of Human Rights (UDHR) and the International Covenant on Civil and Political Rights (ICCPR), limit the right in question to the procedural elements of democracy, in the form of the practice of periodic free and fair elections. The thin procedural view cannot protect democracy against its ideological enemies, and the absence of an instrumental and substantive understanding of democracy, incorporating a number of mutually reinforcing fundamental freedoms and rights, creates considerable ambiguity in the classification of a state as a democracy. With reference to Gregory Fox and Georg Nolte's important article, Intolerant Democracies, one might conclude that the application of a thin version of democracy, as provided in the major treaties, could lead to the empowerment of intolerant actors, who might seek to rely on the procedural standard to justify efforts to eliminate the democratic system entirely. ${ }^{7}$ In contrast, an instrumental account of democracy views the democratic entitlement as a means to achieve further fundamental rights and freedoms, where "liberty" is the ultimate end, and all participants in the democratic process submit to an overlapping consensus. This consensus is one in which they do not aim to achieve their own conception of the good at the expense of others, and do not seek to enforce any comprehensive understanding of a moral truth based on religious, ideological, or political doctrines inconsistent with the universal understanding of human rights, as reflected in foundational international human rights instruments.

\footnotetext{
${ }^{5}$ Human Rights Comm., General Comment No. 25: The Right to Participate in Public Affairs, Voting Rights and the Right of Equal Access to Public Service (Art. 25), UN Doc. CCPR/C/21/Rev.1/Add.7 para. 2 (July 7, 1996).

${ }^{6}$ See Khalifa Alfadhel, The Failure of the Arab Spring (2016).

${ }^{7}$ Gregory H. Fox \& Georg Nolte, Intolerant Democracies, 36 Harv. InT'L L.J. 1 (1995).
} 


\section{A Thicker View: Toward an Instrumental Conception}

While the classic instruments tend toward a thinner view of democracy, more recent developments in international law provide a fuller understanding of the right to democracy, accommodating rigorous substantive elements. The UN Secretary-General has issued a number of foundational reports reiterating the international community's support for democracy, including the Agenda for Democratization ${ }^{8}$ and In Larger Freedom: Towards Development, Security and Human Rights for All. ${ }^{9}$ These were accompanied by a number of UN documents, such as the Vienna Declaration and Programme of Action ${ }^{10}$ and the UN Commission on Human Rights Resolution on Promotion of the Right to Democracy. ${ }^{11}$ The UN General Assembly also contributed to the enhancement of the democracy norm in international law, especially in its UN Millennium Declaration, ${ }^{12}$ and later in the 2005 World Summit Outcome, where it acknowledged the mutually reinforcing nature of democratic governance and human rights. ${ }^{13}$

In addition to these soft-law instruments and the procedural norms provided in the International Bill of Human Rights, regional bodies have issued a considerable number of persuasive instruments reaffirming the right to democratic governance. In Europe, for instance, the Treaty on European Union (Maastricht Treaty) emphasizes democracy as the underpinning of the political system in the European Union. ${ }^{14}$ The Organization of American States adopted Resolution 1080, which indirectly affirmed democracy as a form of government. ${ }^{15}$ And the African Union identified democracy as the desirable form of government in its Constituent Act. ${ }^{16}$ However, the aforementioned examples do not provide any indication of an instrumental right to democracy, as opposed to the mere procedural view.

One source of data that supports the instrumental view is the jurisprudence of the European Court of Human Rights, which has developed a substantive view of democracy in the process of evaluating whether restrictions are "necessary in a democratic society." It also confirmed that this right to democracy was not limited to the procedural elements of periodic elections. In Handyside v. UK, for example, the Court balanced freedom of expression with the question of whether restrictions on freedom of expression were necessary in a democratic society. ${ }^{17}$ Similarly, the Court identified tolerance and pluralism as fundamental components of democracy in United Communist Party of Turkey v. Turkey. ${ }^{18}$ Finally, it confirmed in Refah Partisi (Welfare Party) v. Turkey that intolerant political actors were not to be subject to an overlapping democratic consensus once their declared objective

\footnotetext{
${ }^{8}$ Secretary-General, An Agenda for Democratization, UN Doc. A/51/761 (Dec. 20, 1996). For a detailed assessment on the drafting of this document, see Caroline E. Lombardo, The Making of an Agenda for Democratization: A Speechwriter's View, 2 CHI. J. INT'L L. 253 (2001).

${ }^{9}$ Secretary-General, In Larger Freedom: Towards Development, Security and Human Rights for All, UN Doc. A/59/2005 (Mar. 21 , 2005).

${ }^{10}$ General Assembly, Vienna Declaration and Programme of Action, UN Doc. A/CONF.157/23 (July 12, 1993).

${ }^{11}$ Comm'n on Human Rights, Promotion of the Right to Democracy, UN Doc. E/CN.4/RES/1999/57 (Apr. 27, 1999).

12 United Nations Millennium Declaration, GA Res. 55/2 (Sept. 8, 2000).

132005 World Summit Outcome, G.A. Res. 60/1 para. 119 (Oct. 24, 2005).

${ }_{14}$ Consolidated Version of the Treaty on European Union, Feb. 7, 1992, 2002 O.J. (C 325) 5. See Bojan Bugarič, The Right to Democracy in a Populist Era, 112 AJIL Unbound 79 (2018).

15 Organization of American States, Resolution 1080, AG/RES. 1080 (XXI-O/91) (June 5, 1991).

${ }^{16}$ Organization of African Unity, Constitutive Act of the African Union, July 1, 2000.

${ }^{17}$ Handyside v. UK para. 49, App. No. 5493/72 (Eur. Ct. H.R., Dec. 7, 1976).

${ }^{18}$ United Communist Party of Turkey v. Turk. para. 45, App. No. 19392/92 (Eur. Ct. H.R., Jan. 30, 1998).
} 
was incompatible with the principles of a democratic society. ${ }^{19}$ This final holding was perhaps one of the most significant contributions to the understanding of an instrumental right to democracy.

Yet, despite some normative statements to the contrary, the consistent practice of both states and international organizations such as the United Nations continually push towards the thinner, procedural understanding of democracy. We see this in the limitation of democratization measures to their procedural element, in the form of electoral assistance and technical support. This was indeed the case in the aftermath of the events in the Middle East that are collectively known as the Arab Spring. Much of the international reaction to events in the region simply accepted that whoever was democratically elected had moral legitimacy. Yet in Libya and Egypt, to take two examples, elections produced neither legitimacy nor stability. The experience contributes to the significant conceptual problem associated with the right to democracy in international law: a purely procedural model could make free and fair elections a means to abolish the democratic system.

\section{How to Deepen the Instrumental Model}

The application of an instrumental model of a democratic entitlement requires an extensive restructuring of the understanding of the right to democracy in international law through existing international, regional, and national mechanisms. The Human Rights Committee needs to consider the theoretical elements of a substantive right to democracy when considering state reports and individual communications that challenge state practices under Article 25 of the ICCPR. The jurisprudence of the Committee in conjunction with its relevant General Comment has been inconsistent. The Committee affirmed, for instance-in an isolated case many years agothat a one-party system is compatible with the right to political participation as defined in the Covenant. ${ }^{20}$ This conceptual problem with the right in question, associated with one of the most significant international instruments, cannot be remedied without deeper theoretical consideration of the consent required to establish and sustain democracy. For example, in considering individual communications and state reports, the Committee needs to examine whether state and political actors are committed to democracy in its substantive sense, before it considers the procedural elements of democracy as provided in Article 25 of the Covenant and the relevant jurisprudence. This should extend to an examination of the state's consent to at least some zone of secular morality, where public discourse is not limited by any distinctive religious interpretation, in order to realize the full application of a sustainable right to democracy.

The Universal Periodic Review (UPR) mechanism has proven to be one of the most effective monitoring devices associated with the United Nations and the Human Rights Council. However, it has done little to provide substantive content to the right to democracy. This is because general state practice and the Council's review do not extend to democracy's substantive aspects. The UPR provides an opportunity for developing a thicker conception of the right to democracy, one that emphasizes its role as an instrument to protect other fundamental values.

The UN's general attitude towards democratic transition has emphasized technical and electoral assistance. This approach has proven to be of little effect, at least in circumstances in which active groups in transitional societies seek to use the procedural element of democracy to abolish or replace the system. Such technical assistance should be extended to include education in the theoretical underpinnings of democracy, so as to establish a firm foundation of democracy based on the consent of all stakeholders.

States should extend the mandate of the Electoral Assistance Division in the UN Department of Political Affairs to include the substantive and theoretical aspects of democracy, beyond the procedural content of the

${ }^{19}$ Refah Partisi (Welfare Party) v. Turk., App. Nos. 41340/98, 41342/98, and 41344/98, Judgment of the Grand Chamber (Eur. Ct. H. R., Feb. 13, 2003).

${ }^{20}$ Human Rights Comm., Bwalya v. Zambia, Communication No. 314/1988, UN Doc. CCPR/C/48/D/314/1988 (July 27, 1993). 
notion. Technical assistance should include training and capacity-building directed primarily towards citizens, who are the primary decision-makers in a democratic society. It must seek extensive awareness of the substantive and instrumental merits of democracy, not just a procedural understanding of the term, which could lead to an undesirable outcome. Such bodies should focus on challenging the status quo ante of religious dominance and political intolerance through the education of citizens on the importance of civil disagreement.

The Security Council has also played a significant role in the promotion of democracy in the international arena. The mandates of support missions commissioned by the Security Council (as was the case in Libya) should affirm the importance of the main pillars of democracy, and should consider the substance of the instrumental right to democracy before the conduct of national elections. Such confirmation by the Security Council will express a determined international stance that will not only influence state practice but also the behavior of international organizations, and would elevate the right to democracy in international law.

Future Security Council resolutions establishing support missions in transitional democracies need to recognize the status quo ante in the given societies, in order to fully comprehend the consequences of applying a procedural right to democracy. This requires the extension of the mandates of support missions to include the examination of the consent of all relevant parties to substantive democracy, and to insist on reasonable tolerance of disagreement and secularism. While the United Nations is not necessarily in a position to ban parties on its own, it must recognize the problem of the undemocratic political party that seeks to compete in elections. In addition, UN Special Rapporteurs and independent human rights experts, especially those with country mandates, need to emphasize elements of the instrumental right to democracy in their assessments. This approach will help provide a formula not only for the application of the right to democracy, but also all other mutually reinforcing rights that are associated with it. These actions will help sustain democracy and the realization of stability, sustainability, and development in countries that need the most attention.

On the national level, the application of the instrumental right to democracy must be grounded at the grassroots, given that it places central importance on the citizen, who is the primary decision-maker in a democratic society. In order for citizens to be committed to democracy, states must provide extensive and effective civic education in all teaching levels. This must include the instruction of the principles of toleration, rationality, and an emphasis on the content and scope of the right to democracy in international law (widely defined). The education program must highlight the threat of political intolerance, and articulate how it could produce negative outcomes in any political society. Such education should address all political groups, including those grounded in religious or moral positions, national civil servants associated with the democratization process, members of legislative and municipal councils, and all relevant stakeholders, who either represent the intolerant nonstate actors or the state. While it may be the case that states in most need of such civic education programs will be resistant to conducting them, because of their antidemocratic or intolerant leadership, this does not mean that the task is impossible. Such a civic education program could be carried out with the assistance of the UN Development Programme and other relevant international and regional bodies. Constitution-making in transitional societies that lack a long democratic tradition must also incorporate the instrumental understanding of democracy, and international cooperation can help in this regard.

\section{Conclusion}

In conclusion, let me return to the main question: is there a right to democracy in international law? My answer is affirmative, but qualified: the nature of the entitlement is procedural, limited to periodic free and fair elections. Is this worth celebrating, in terms of the universality of the democratic ideal? Not at all. So long as the right to democracy is not an instrumental one, designed to achieve further rights and freedoms necessary for the sustainability of democratic values, we will not have reached any end of history. 